\title{
Author Correction: Loss of SNORA73 reprograms cellular metabolism and protects against steatohepatitis
}

Arthur C. Sletten, Jessica W. Davidson, Busra Yagabasan (10), Samantha Moores, Michaela Schwaiger-Haber (D), Hideji Fujiwara, Sarah Gale, Xuntian Jiang, Rohini Sidhu, Susan J. Gelman, Shuang Zhao, Gary J. Patti@,

Daniel S. Ory \& Jean E. Schaffer (1)

Correction to: Nature Communications https://doi.org/10.1038/s41467-021-25457-y, published online 01 September 2021.

In this article, the author names Susan J. Gelman and Gary J. Patti were incorrectly written as Susan Gelman and Gary Patti. The original article has been corrected.

Published online: 24 November 2021

(c) (i) Open Access This article is licensed under a Creative Commons Attribution 4.0 International License, which permits use, sharing, adaptation, distribution and reproduction in any medium or format, as long as you give appropriate credit to the original author(s) and the source, provide a link to the Creative Commons license, and indicate if changes were made. The images or other third party material in this article are included in the article's Creative Commons license, unless indicated otherwise in a credit line to the material. If material is not included in the article's Creative Commons license and your intended use is not permitted by statutory regulation or exceeds the permitted use, you will need to obtain permission directly from the copyright holder. To view a copy of this license, visit http://creativecommons.org/licenses/by/4.0/.

(c) The Author(s) 2021 